\title{
FAKTOR-FAKTOR YANG BERHUBUNGAN DENGAN KEPATUHAN PEDAGANG DALAM PELAKSANAAN PROTOKOL KESEHATAN COVID-19 DI PASAR PETISAH KOTA MEDAN SUMATERA UTARA
}

\author{
Rimenda Putri Tetartor $\mathbf{S}^{1}$, Isabela Anjani ${ }^{2}$, Mafe Robbi Simanjuntak ${ }^{3}$, \\ Dameria $^{4}$ \\ 1-4Universitas Prima Indonesia Jalan Sekip Jalan Sikambing, Sei Putih Tim. I, \\ Kec. Medan Petisah, Kota Medan, Sumatera Utara 20111 \\ e-mail: putritetartos@gmail.com \\ DOI $10.35451 / \mathrm{jkg} . \mathrm{v} 3 \mathrm{i} 2.489$
}

\begin{abstract}
Petisah Market is one of the markets in Medan City where company regional market requires traders to apply health protocols during the July purchase of goods. This study aims to determine education, knowledge, attitudes, social environment, and sources of information on Trader Compliance with the Implementation of the Covid-19 Health Protocol in Petisah Market, Medan City, North Sumatra. This type of research is a quantitative study using a cross sectional study design. The research sample consisted of 83 people. The results of this study were tested statistically using the Chi Square Test with a 95\% confidence level using SPSS software. The results showed that the $P$-Value for education was $0.000(0.000<0.05)$, the $P$-Value for knowledge was 0.004 $(0.004<0.05)$, the P-Value for attitude was $0.000(0.000<0.05)$, the $P$-value for knowledge -The social environment value is $0.143(0.143>0.05)$, the $P$ value of the information source is $0.296(0.296<0.05)$. The conclusion is that there is a relationship between education, knowledge, and attitudes towards Trader Compliance with the Implementation of the Covid-19 Health Protocol in Pasar Petisah Kota Medan, North Sumatra, while the Social Environment and sources of information are not related to the Implementation of the Covid-19 Health Protocol in the Petisah Market, Medan City, North Sumatra. It is recommended that traders and the public are expected to increase their knowledge (understanding) about Covid-19 and continue to carry out the Covid19 health protocol wherever they are in order to avoid the transmission of the Covid-19 disease.
\end{abstract}

\section{Keywords: Health protocol, knowledge, attitude}

\section{PENDAHULUAN}

Coronavirus adalah virus yang dapat menyebabkan suatu penyakit pada manusia dan hewan. Jenis penyakit coronavirus menyebabkan infeksi saluran pernafasan seperti batuk pilek dan lebih serius lagi coronavirus dapat menyebabkan penyakit Middle East Respiratory Sindrome (MERS) dan Severe Acute Respiratory Sindrome
(SARS) (Kemenkes R I, 2020b; WHO, 2020). Covid-19 merupakan salah satu jenis penyakit coronavirus yang baru ditemukan dan mewabah di wilayah Wuhan pada akhir tahun 2019. Coronavirus merupakan zoonosis (ditularkan antara hewan dan manusia) (Kemenkes RI, 2020b).

Pada tanggal 31 Desember 2019 telah ditemukan 27 orang mengalami 
pneumonia di China telah dilaporakan ke Badan Kesehatan Dunia, dan pada tanggal 11 maret 2020 WHO menetapkan penyakit Covid-19 sebagai Pandemi (Kemenkes R I, 2020b; WHO, 2020).

Negara Thailand adalah negara pertama yang melaporkan kasus Covid19, negara lain yang juga melaporkan kasus Covid-19 adalah negara Jepang dan Korea Selatan. Dalam waktu singkat penyebaran dan jumlah kasus penyakit Covid-19 di berbagai negara semakin meningkat. Pada tanggal 2 Maret 2020 Indonesia melaporkan kasus Covid-19 dan semakin bertambah sampai saat ini. Jumlah kasus Covid-19 di Indonesia hingga tanggal 17 Juli 2020 telah mencapai 81.668 kasus dengan angka kematian 3.873 kasus (Kemenkes R I, 2020b; worldometers, 2020).Salah satu wilayah zona merah Covid-19 adalah Sumatera utara dengan jumlah kasus 2.693 kasus dengan jumlah kasus yang meninggal sebesar 136 kasus (Gugus Covid-19, 2020).

Penularan penyakit Covid-19 dari orang ke orang dapat terjadi melalui droplet dan kontak langsung dengan virus, selanjutnya virus masuk kedalam saluran pernapasan. Sebuah analisis telah dilakukan untuk menentukan laju penularan Covid-19 berdasarkan masa inkubasi, gejala antar pasien yang telah di isolasi hasilnya 1 pasien Covid-19 dapat menularkan kepada 3 orang yang berada disekitarnya (Zhu et al., 2020).

Dalam upaya penanggulangan penyebaran Covid-19 Menteri Kesehatan Menetapkan Protokol Kesehatan di tempat dan Fasilitas Umum agar menjadi acuan dalam melakukan aktivitas kegiatan pasar (Kemenkes R I, 2020a). Salah satu pasar tradisional/ pasar rakyat yang berada di Kota Medan adalah Pasar Petisah. Berdasarkan survei awal yang dilakukan peneliti bersama dengan PD Pasar Petisah ditemukan bahwa pedagang yang memiliki kios di pasar petisah masih banyak yang belum menggunakan masker, selain itu pedagang pasar petisah juga belum memanfaatkan sarana cuci tangan yang telah disediakan. Sementara itu berdasarkan penjelesan PD Pasar Petisah mereka telah melakukan sosialisasi terhadap para pedagang agar tetap melakukan protokol kesehatan.

Pengetahuan pedagang sebagai faktor predisposisi yang dapat membentuk perilaku pedagang dalam menerapkan protokol kesehatan (Adliyani et al., 2017; Notoatmodjo, 2003). Sumber informasi yang banyak dapat memungkinkan seseorang untuk mengakses informasi dengan baik, ma akan menghasilkan pengetahuan yang baik sehingga mendukung terciptanya perilaku yang baik (Notoatmodjo, 2003; Samidah et al., 2017).

Sikap sebagai bagian dari respon evaluatif yang timbul pada saat seseorang dihadapkan pada stimulus sehingga menghasilkan reaksi. Sikap merupakan suatu bentuk dari pengetahuan tetapi disertai dengan kecenderungan untuk bertindak sesuai dengan pengetahuan (Notoatmodjo, 2003; Sobur, 2011).

Lingkungan sosial merupakan salah satu faktor penguat untuk mendukung individu dalam melakukan/menerapkan kebijakan kesehatan(Ahmadi \& Uhbiyati, 1991). Lingkungan sosial yang terbawa sebelum masa pandemi Covid-19 dapat saja mempengaruhi penerapan protokol kesehatan Covid-19. Ketidakbiasaan melakukan hal-hal baru dapat menjadi faktor pedagang tidak menerapkan protokol kesehatan Covid-19.

Tujuan penelitian ini adalah untuk melihat hubungan pendidikan, pengetahuan, sikap, lingkungan sosial, dan sumber informasi terhadap Kepatuhan Pelaksanaan Protokol 
Kesehatan Covid-19 di Pasar Petisah Kota Medan Sumatera Utara".

\section{METODE}

Jenis penelitian ini adalah penelitian deskriptif dengan pendekatan kualitatif dengan rancangan cross sectional. Penelitian ini dilakukan pada pedagang Pasar Petisah Kota Medan Sumatera Utara pada Bulan Agustus tahun 2020.

Populasi penelitian ini adalah seluruh pedagang Pasar Petisah Kota Medan Sumatera Utara yaitu sebanyak 500 Pedagang. Jumlah sampel dalam penelitian ini dihitung dengan menggunakan rumus slovin sebagai berikut:

$$
\begin{aligned}
& \mathrm{n}=\mathrm{N} /\left(1+\left(\mathrm{N}^{\mathrm{N}} \mathrm{e}^{2}\right)\right) \\
& \text { Sehingga: } \\
& \mathrm{n}=500 /\left(1+\left(500 \times 0,1^{2}\right)\right) \\
& \mathrm{n}=500 /(1+(500 \times 0,1)) \\
& \mathrm{n}=500 /(1+5) \\
& \mathrm{n}=500 / 6 \\
& \mathrm{n}=83,33
\end{aligned}
$$

Ket:

$$
\begin{aligned}
& \mathrm{n}=\text { Sampel } \\
& \mathrm{N}=\text { populasi } \\
& \mathrm{e}=\text { margin of error' }(90 \%)
\end{aligned}
$$

Berdasarkan perhitungan sampel dengan rumus slovin diatas maka jumlah sampel dalam penelitian ini adalah sebanyak 83 sampel. Teknik pengambilan sampel yang digunakan dalam penelitian ini adalah random sampling yang artinya setiap pedagang yang memiliki kios di Pasar Petisah memiliki kesempatan yang sama untuk dijadikan sebagai sampel.

Penelitian ini dilakukan dengan cara melakukan wawancara dengan responden dan kemudian mengobservasi tindakan responden. Setelah data terkumpul peneliti kemudian melakukan entry data dan melakukan analisis univariat dan analisis bivariat dengan uji Chi-Square dengan tingkat kepercayaan 95\% $(a=0,05)$.
HASIL

\section{Analisis Univariat}

Analisis Univariat dilakukan untuk melihat distribusi frekuensi yang meliputi umur, jenis kelamin, pendidikan terakhir, Pengetahuan, sikap, lingkungan sosial, sumber informasi, dan kepatuhan pelaksanaan protokol kesehatan Covid-19.

\section{Distribusi Frekuensi Responden} Berdasarkan Umur, Jenis Kelamin, dan Pendidikan Terakhir Responden

Berdasarkan kelas interval diperoleh distribusi berdasarkan umur, jenis kelamin pendidikan terakhir responden dilihat pada tabel 1 dibawah ini.

Tabel 1. Distribusi Frekuensi Karakteristik Responden

\begin{tabular}{lcc}
\hline Variabel & $\begin{array}{l}\text { Jumlah } \\
(\mathbf{n})\end{array}$ & Frekuensi \\
\hline Umur & & \\
\hline 17-35 Tahun & 25 & 30,1 \\
>35 Tahun & 58 & 69,9 \\
\hline Jenis Kelamin & & \\
\hline Laki-Laki & 28 & 33,7 \\
Perempuan & 55 & 66,3 \\
\hline Pendidikan & & \\
Terakhir & & \\
\hline Tidak Sekolah/SD & 5 & 6,0 \\
SMP & 7 & 8,4 \\
SMA & 55 & 66,3 \\
D3/S1 & 16 & 19,3 \\
\hline Total & $\mathbf{8 3}$ & $\mathbf{1 0 0 , 0}$
\end{tabular}

Sumber: Data primer, 2020

Berdasarkan tabel 1 diatas dapat diketahui bahwa mayoritas responden berumur $>35$ tahun yaitu sebanyak 58 orang $(69,9)$, mayoritas responden adalah perepuan yaitu sebanyak 55 orang $(66,3 \%)$, mayoritas pendidikan terkhir responden adalah SMA yaitu sebanyak 55 orang $(66,3 \%)$.

\section{Distribusi Frekuensi Responden Berdasarkan Pengetahuan, Sikap, Lingkungan Sosial, Sumber Informasi dan Kepatuhan Pelaksanaan Protokol Kesehatan Covid-19}


Berdasarkan kelas interval
diperoleh distribusi berdasarkan Pengetahuan, Sikap, Lingkungan Sosial, Sumber Informasi dan Kepatuhan Pelaksanaan Protokol Kesehatan Covid19 responden dilihat pada tabel 2 dibawah ini.

Tabel 2 Distribusi Frekuensi Variabel Penelitian

\begin{tabular}{lcc}
\hline Variabel & $\begin{array}{l}\text { Jumlah } \\
(\mathbf{n})\end{array}$ & Frekuensi \\
\hline Pengetahuan & & \\
\hline Kurang baik & 52 & 62,7 \\
Baik & 31 & 37,3 \\
\hline Sikap & & \\
\hline Kurang baik & 66 & 79,5 \\
Baik & 17 & 20,5 \\
\hline Lingkungan & & \\
Sosial & & \\
\hline $\begin{array}{l}\text { Buruk } \\
\text { Baik }\end{array}$ & 11 & 13,3 \\
\hline Sumber & 72 & 86,7 \\
Informasi & & \\
\hline $\begin{array}{l}\text { Buruk } \\
\text { Baik }\end{array}$ & 6 & 7,2 \\
\hline Kepatuhan & & 92,8 \\
$\begin{array}{l}\text { Protokol } \\
\text { Kesehatan }\end{array}$ & & \\
Covid-19 & & \\
\hline Buruk & & \\
Baik & 71 & 85,5 \\
\hline Total & 12 & 14,5 \\
\hline
\end{tabular}

Sumber: Data primer, 2020

Berdasarkan tabel 2 diatas dapat diketahui bahwa mayoritas pengetahuan responden Kurang baik yaitu sebanyak 52 orang $(62,7)$, mayoritas sikap responden kurang baik

Tabel 3 Hubungan Pendidikan, Pengetahuan, Sikap, Lingkungan Sosial dan Sumber Infromasi Dengan Pelaksanaan Protokol Kesehatan Covid-19

\begin{tabular}{|c|c|c|c|c|c|c|c|}
\hline \multirow{3}{*}{ Variabel } & \multicolumn{4}{|c|}{ Kepatuhan Protokol Kesehatan } & \multirow{2}{*}{\multicolumn{2}{|c|}{ Total }} & \multirow{3}{*}{$\begin{array}{c}\text { P } \\
\text { Value }\end{array}$} \\
\hline & \multicolumn{2}{|c|}{ Tidak Patuh } & \multicolumn{2}{|c|}{ Patuh } & & & \\
\hline & $\mathrm{n}$ & $\%$ & $\mathrm{n}$ & $\%$ & $\mathrm{n}$ & $\%$ & \\
\hline \multicolumn{8}{|l|}{ Pendidikan } \\
\hline Tidak Sekolah/SD & 5 & 100,0 & 0 & 0,0 & 5 & 100 & \multirow{4}{*}{0,000} \\
\hline SMP & 7 & 100,0 & 0 & 0,0 & 7 & 100 & \\
\hline SMA & 51 & 92,7 & 4 & 7,3 & 55 & 100 & \\
\hline D3/S1 & 8 & 50,0 & 8 & 50,0 & 16 & 100 & \\
\hline \multicolumn{8}{|l|}{ Pengetahuan } \\
\hline Kurang Baik & 40 & 76,9 & 12 & 23,1 & 52 & 100 & 0,004 \\
\hline Baik & 31 & 100 & 0 & 0,00 & 31 & 100 & \\
\hline
\end{tabular}

yaitu sebanyak 66 orang $(79,5 \%)$, mayoritas lingkungan sosial responden menyatakan baik yaitu sebanyak 72 orang $(86,7 \%)$, mayoritas sumber informasi responden menyatakan baik yaitu sebanyak 77 orang $(92,8 \%)$, mayoritas penerapan kepatuhan Protokol kesehatan Covid-19 responden buruk yaitu sebanyak 71 orang $(85,5 \%)$,

\section{Analisi Bivariat}

Analisis Bivariat dilakukan untuk mengetahui hubungan antara Pendidikan, pengetahuan, sikap, lingkungan sosial, dan sumber informasi terhadap pelaksanaan protokol kesehatan Covid-19 di Pasar Petisah Kota Medan Tahun 2020.

\section{Hubungan Pendidikan, Pengetahuan, Sikap, Lingkungan Sosian dan Sumber Informasi Dengan Pelaksanaan Protokol Kesehatan Covid-19 di Pasar Petisah Kota Medan Tahun 2020.}

Hubungan

Pendidikan, pengetahuan, sikap, lingkungan sosial, dan sumber informasi Dengan Pelaksanaan Protokol Kesehatan Covid19 di Pasar Petisah Kota Medan Tahun 2020 dapat dilihat pada tabel 3 dibawah ini. 


\begin{tabular}{lccccccc}
\hline Sikap & & & & & & & \\
\hline Buruk & 61 & 92,4 & 5 & 7,6 & 66 & 100 & 0,000 \\
Baik & 10 & 58,8 & 7 & 41,2 & 17 & 100 & \\
\hline $\begin{array}{l}\text { Lingkungan } \\
\text { Sosial }\end{array}$ & & & & & & & \\
\hline Buruk & 11 & 100,0 & 0 & 0,0 & 11 & 100 & 0,143 \\
Baik & 60 & 83,3 & 12 & 16,7 & 72 & 100 & \\
\hline Sumber & & & & & & & \\
Informasi & 6 & 100,0 & 0 & 0,0 & 6 & 100 & 0,296 \\
\hline Buruk & 65 & 84,4 & 12 & 15,6 & 77 & 100 & \\
Baik & & & & & & \\
\hline
\end{tabular}

Sumber: Data primer, 2020

Berdasarakan tabel 3

memperlihatkan bahwa mayoritas pendidikan terkhir responden adalah SMA yaitu sebanyak 55 orang $(66,3 \%)$. Berdasarkan chi square $p$-Value < dari a $(0,000<0,05)$, dengan demikian dapat diketahui bahwa Ho ditolak dan $\mathrm{Ha}$ diterima, artinya bahwa ada hubungan pendidikan dengan protokol kesehatan Covid-19.

Berdasarkan tabel 3 memperlihatkan bahwa mayoritas pengetahuan responden adalah Kurang baik yaitu sebanyak 52 orang $(62,7)$. Berdasarkan chi square $p$-Value < dari a $(0,004<0,05)$, dengan demikian dapat diketahui bahwa $\mathrm{Ho}$ ditolak dan $\mathrm{Ha}$ diterima, artinya bahwa ada hubungan pengetahuan dengan protokol kesehatan Covid-19.

Berdasarkan tabel 3 memperlihatkan bahwa mayoritas sikap responden adalah kurang baik yaitu sebanyak 66 orang (79,5\%). Berdasarkan chi square $p$-Value < dari a $(0,000<0,05)$, dengan demikian dapat diketahui bahwa Ho ditolak dan $\mathrm{Ha}$ diterima, artinya bahwa ada hubungan sikap dengan protokol kesehatan Covid19.

Berdasarkan tabel 3 memperlihatkan bahwa mayoritas lingkungan sosial responden menyatakan baik yaitu sebanyak 72 orang $(86,7 \%)$. Berdasarkan chi square $p$-Value > dari a $(0,143>0,05)$, dengan demikian dapat diketahui bahwa Ho ditolak dan Ha diterima, artinya bahwa tidak ada hubungan lingkungan sosial dengan protokol kesehatan Covid-19.

Berdasarkan tabel 3 memperlihatkan bahwa mayoritas sumber informasi responden menyatakan baik yaitu sebanyak 77 orang (92,8\%). Berdasarkan chi square $p$-Value > dari a $(0,296>0,05)$, dengan demikian dapat diketahui bahwa Ho ditolak dan Ha diterima, artinya bahwa tidak ada hubungan Sumber informasi dengan protokol kesehatan Covid-19.

\section{PEMBAHASAN}

\section{Hubungan Pendidikan Dengan Pelaksanaan Protokol Kesehatan Covid-19 di Pasar Petisah Kota Medan Tahun 2020.}

Berdasarkan chi square $p$-Value $<$ dari a $(0,000<0,05)$, dengan demikian dapat diketahui bahwa Ho ditolak dan Ha diterima, artinya bahwa ada hubungan pendidikan dengan protokol kesehatan Covid-19.

Tingkat pendidikan pedagang sangat berhubungan terhadap sikap yang menuju pelaksanaan protokol kesehatan Covid-19. Tingkat pendidikan pedagang yang rendah akan berhubungan dalam proses analisis sebuah informasi yang diperoleh yang diwujudkan dalam sebuah tindakan. Hasil penelitian menunjukkan bahwa semakin tinggi jenjang pendidikan responden maka responden akan semakin patuh dalam penerapan protokol kesehatan Covid-19. 


\begin{abstract}
Sander (2005) menyatakan bahwa semakin tinggi pendidikan seseorang maka akan berpengaruh terhadap pelaksanaan kesehatan masyarakat, rendahnya pendidikan seseorang akan menyebabkan kurangnya kesadaran orang tersebut dalam peningkatan kesehatannya. Semakin baik pendidikan formal seseorang akan meningkatkan pemahaman orang tersebut tentang pentingnya kesehatan sehingga hal ini akan mempengaruhi kesadaran perilaku kesehatannya (Sander, 2005). Amalia Imanda (2009) juga menyatakan pendapat yang sama yakni menyatakan bahwa pendidikan sangat berpengaruh terhadap pencegahan penyakit di lingkungan pasar. Pendidikan yang tinggi akan menpengaruhi pola pikir seseorang terhadap pencegahan penyakit dengan penerapan perilaku hidup bersih dan sehat di pasar kliwon dan Jebres Kota Surakarta (Amalia, 2019).
\end{abstract}

\section{Hubungan Pengetahuan Dengan Pelaksanaan Protokol Kesehatan Covid-19 di Pasar Petisah Kota Medan Tahun 2020.}

Berdasarkan chi square $p$-Value $<$ dari a $(0,004<0,05)$, dengan demikian dapat diketahui bahwa Ho ditolak dan Ha diterima, artinya bahwa ada hubungan pengetahuan dengan protokol kesehatan Covid-19.

Pengetahuan pedagang sebagai faktor predisposisi yang dapat membentuk perilaku pedagang dalam menerapkan protokol kesehatan. Pengetahuan yang baik akan sebuah kebiajakan akan mendukung pelaksanaan kebijakan tersebut, dan sebaliknya pengetahuan yang kurang baik akan berdampak negatife terhadap kebijakan tersebut (Adliyani et al., 2017; Notoatmodjo, 2003). Pengetahuan yang baik biasanya dipengaruhi oleh tingkat pendidikan yang tinggi. Semakin tinggi tingkat pendidikan seseorang maka orang tersebut akan semakin aktif dalam mencari informasi-informasi kesehatan (Notoatmodjo, 2003; Putri, 2017).

$$
\text { Siswani dan Rizki (2018) }
$$

menyatakan bahwa pengetahuan memiliki pengaruh yang signifikan terhadap pelaksanaan pencegahan penyakit dengan penerapan PBHS. Semakin baik dan semakin benar pemahaman atau pengetahuan individu tentang masalah kesehatan maka akan semakin baik juga tindakan individu dalam pencegahan penyakit tersebut (Siswani \& Rizky, 2018). Dalam penelitian ini peneliti menemukan bahwa kurang baiknya pemahaman pedagang tentang Covid-19 maka hal tersebut mengakibatkan pedagang masih mengabaikan protokol kesehatan Covid-19. Peningkatan pengetahuan pedagang diperlukan agar pedagang selalu menerapkan protokol kesehatan Covid-19 sehingga mencegah pedagang tertular penyakit Covid-19 sehingga dapat meningkatkan derajat kesehatannya.

\section{Hubungan Sikap Dengan Pelaksanaan Protokol Kesehatan Covid-19 di Pasar Petisah Kota Medan Tahun 2020.}

Berdasarkan chi square $p$-Value $<$ dari a $(0,000<0,05)$, dengan demikian dapat diketahui bahwa Ho ditolak dan $\mathrm{Ha}$ diterima, artinya bahwa ada hubungan sikap dengan protokol kesehatan Covid-19.

Sikap merupakan suatu bentuk dari pengetahuan tetapi disertai dengan kecenderungan untuk bertindak sesuai dengan pengetahuan (Notoatmodjo, 2003; Sobur, 2011). Handayani (2010) menyatakan bahwa sikap merupakan sebuah reaksi terhadap perasaan yang mendukung ataupun yang tidak mendukung pada objek tersebut (Handayani \& Setyawan, 2015). 
Penelitian ini seseuai dengan penelitian yang dilakukan oleh Siswani dan Rizki (2018) di Kelurahan Cijantung Kec. Pasar Rebo yang menyatakan ada hubungan sikap dengan pencegahan penyakit dengan penerapan PHBS dengan nilai P-value sebesar 0,002 (Siswani \& Rizky, 2018).

Berdasarkan hasil penelitian dilapangan peneliti berasumsi bahwa semakin buruk sikap individu terhadap pencegahan penyakit maka akan semakin buruk juga tindakan yang individu lakukan. Teori Azwar (2005) mengatakan bahwa ada berbagai aspek yang dapat mempengaruhi terbentuknya sikap individu yaitu dari pengalaman, kebudayaan dimana dia tinggal, orang lain dilingkungan nya, media massa, institusi pendidikan dan motivasi dalam diri individu (Azwar, 2005).

\section{Hubungan Lingkungan Sosial Dengan Pelaksanaan Protokol Kesehatan Covid-19 di Pasar Petisah Kota Medan Tahun 2020.}

Berdasarkan chi square $p$-Value $>$ dari a $(0,143>0,05)$, dengan demikian dapat diketahui bahwa Ho ditolak dan Ha diterima, artinya bahwa tidak ada hubungan lingkungan sosial dengan protokol kesehatan Covid-19.

Lingkungan sosial merupakan salah satu faktor penguat untuk mendukung individu dalam melakukan/menerapkan kebijakan kesehatan (Ahmadi \& Uhbiyati, 1991). Individu yang bekerja diluar rumah atau menghabiskan banyak waktu di luar rumah memiliki cakupan lingkungan sosial yang lebih luas daripada mereka yang tidak bekerja. Beberapa kegiatan individu seperti cara berpkaian, konsumsi makanan, cara berbicara dapat dipengaruhi oleh lingkungan sosial termasuk didalamnya lingkungan kerja. Lingkungan sosial atau lingkungan kerja dapat mempengaruhi perilaku individu terhadap sesuatu pemahamannya (Wantiyah, 2004).

Penelitian ini tidak sesuai dengan penelitian yang dilakukan oleh Surjadi (2012) yang mengatakan bahwa ada pengaruh lingkungan individu dengan peningkatan derajat kesehatannya (Surjadi, 2012). Berdasarkan hasil penelitian di lapangan bahwa diketahui lingkungan sisoal pedangang tidak memiliki hubungan terhadap pelaksanaan protokol kesehatan. Peneliti berasumsi bahwa lingkungan sosial baik namun tidak menunjukkan tindakan pedagang dalam penerapan protokol kesehatan Covid-19 begitu juga sebaliknya bahwa lingkungan sosial yang buruk namun pedagang tetap menunjukkan tindakan yang patuh dalam penerapan protokol kesehatan Covid-19.

\section{Hubungan Sumber Informasi Dengan Pelaksanaan Protokol Kesehatan Covid-19 di Pasar Petisah Kota Medan Tahun 2020.}

Berdasarkan chi square $p$-Value $>$ dari a $(0,296>0,05)$, dengan demikian dapat diketahui bahwa Ho ditolak dan Ha diterima, artinya bahwa tidak ada hubungan Sumber informasi dengan protokol kesehatan Covid-19.

Sumber informasi yang banyak dapat memungkinkan seseorang untuk mengakses informasi dengan baik, namun sebaliknya jika sumber informasi yang diperoleh seseoarang tidak baik maka akan mengahasilkan output yang tidak baik pula. Informasi yang baik akan menghasilkan pengetahuan yang baik sehingga mendukung terciptanya perilaku yang baik (Notoatmodjo, 2003; Samidah et al., 2017).

Berdasarkan hasil penelitian dilapangan peneliti berasumsi bahwa tidak semua sumber informasi yang diperoleh pedagang dijadikan sebagai suatu bentuk pengetahuan yang 
berguna dalam penerapan protokol kesehatan Covid-19. Hal ini sesuai dengan penelitian yang dilakukan oleh Nurmansyah dkk (2012) yang mengatakan bahwa tidak semua sumber informasi dimanfaatkan dalam peningkatan pengetahuan. Dalam penelitian ini juga dapat kita ketahui bahwa walaupun sumber informasi pedagang sudah baik namun dalam hal penerapan nya pedagang belum secara sadar dalam menerapkan protokol kesehatan Covid-19 untuk mencegah penularan penyakit Covid-19.

\section{KESIMPULAN}

Hasil analisis dan pembahasan yang dilakukan peneliti pada penelitian tentang Faktor-Faktor yang Berhubungan Kepatuhan Pedagang terhadap Pelaksanaan Protokol Kesehatan Covid-19 di Pasar Petisah Kota Medan Sumatera Utara, diperoleh kesimpulan sebegai berikut:

1. Ada Hubungan pendidikan, pengetahuan, sikap terhadap Kepatuhan Pedagang terhadap Pelaksanaan Protokol Kesehatan Covid-19 di Pasar Petisah Kota Medan Sumatera Utara

2. Tidak Ada hubungan Lingkungan Sosial dan sumber informasi terhadap Pelaksanaan Protokol Kesehatan Covid-19 di Pasar Petisah Kota Medan Sumatera Utara

\section{DAFTAR PUSTAKA}

Adliyani, Z. O. N., Angraini, D. I., \& Soleha, T. U. (2017). Pengaruh pengetahuan, pendidikan dan ekonomi terhadap perilaku hidup bersih dan sehat pada masyarakat Desa Pekonmon Kecamatan Ngambur Kabupaten Pesisir Barat. Majority, 7(1), 6-13.

Ahmadi, A., \& Uhbiyati, N. (1991). Ilmu Pendidikan. Rineka Cipta.

Amalia, I. (2019). Hubungan Antara Pendidikan, Pendapatan Dan Perilaku Hidup Bersih Dan Sehat
(Phbs) Pada Pedagang Hidangan Istimewa Kampung (Hik) Di Pasar Kliwon Dan Jebres Kota Surakarta. In Journal of Chemical Information and Modeling (Vol. 53, Nomor 9). https://doi.org/10.1017/CBO9781 107415324.004

Azwar, S. (2005). Sikap Manusia "Teori dan Pengukurannya." Pustaka Pelajar.

Gugus Covid-19. (2020). No TitleSituasi COVID-19 di Sumatera Utara. http://covid19.sumutprov.go.id/

Handayani, \& Setyawan. (2015). Hubungan Pengetahuan dengan Sikap Seks Pranikah Pada Siswa SMAN 1 Kandanghaur Indramayu. Jurnal Kesehatan Masyarakat, Vol. 1, No. 2 Agustus 2015. Jurnal Kesehatan Masyarakat, 1(2).

Kemenkes R I. (2020a). KEPUTUSAN MENTERI KESEHATAN REPUBLIK INDONESIA NOMOR HK.01.07/MENKES/382/2020 TENTANG PROTOKOL KESEHATAN BAGI MASYARAKAT DI TEMPAT DAN FASILITAS UMUM DALAM RANGKA PENCEGAHAN DAN PENGENDALIAN CORONA VIRUS DISEASE 2019 (COVID-19) (hal. 166).

Kemenkes R I. (2020b). Pedoman dan Pengendalian Coronavirus Disease (COVID-19).

Notoatmodjo, S. (2003). Pendidikan Kesehatan dan Ilmu Perilaku. Rineka Cipta.

Putri, R. (2017). Hubungan Antara Tingkat Penndidikan dan Tingkat Pengetahuan dengan Perilaku. https://doi.org/10.1017/CBO9781 107415324.004

Samidah, I. D. A., Murwati, \& Yuhasri, E. (2017). Hubungan Pemanfaatan Sumber Informasi Kesehatan Reproduksi Dengan Sikap Dan Perilaku. 5(2), 60-67.

Sander. (2005). Hubungan Faktor Sosio Budaya Dengan Kejadian Diare di Desa Candinegoro Kecamatan Wonoayu Sidoarjo. Jurnal Medikal, 2(2), 163-193.

Siswani, S., \& Rizky, C. (2018). Hubungan Antara Pengetahuan IBu Rumah Tangga Dengan Penerapan PHBS Di Wilayah RW 07 Kelurahan 
Cijantung Kecamatan Pasar Rebo Jakarta Timur Tahun 2017. Jurnal Kesehatan Masyarakat, 2(1), 1631.

Sobur. (2011). Psikologi umum. Pustaka Setia.

Surjadi, C. (2012). Penerapan pendekatan sosial dan ekologi pada upaya promosi kesehatan implementation of socioecology approach to health promotion effort. Jumal Ekologi Kesehatan, Vol. $11 \mathrm{No}(3), 178-187$.

Wantiyah. (2004). Gambaran Perilaku Hidup Bersih dan Sehat Pada Tatanan Rumah Tangga di RW 04 Kelurahan Terban Wilayah Kerja Puskesmas Gondokusuman II Yogyakarta.

WHO. (2020). Pertanyaan dan jawaban terkait Coronavirus. \%0APertanyaan dan jawaban terkait Coronavirus

worldometers. (2020). Reported Cases and Deaths by Country, Territory, or Conveyance. https://www.worldometers.info/co ronavirus/

Zhu, N., Zhang, D., Wang, W., Li, X., Yang, B., Song, J., Zhao, X., Huang, B., Shi, W., Lu, R., Niu, P., Zhan, F., Ma, X., Wang, D., Xu, W., Wu, G., Gao, G. F., \& Tan, W. (2020). A novel coronavirus from patients with pneumonia in China, 2019. New England Journal of Medicine, 382(8), 727-733. https://doi.org/10.1056/NEJMoa20 01017 